\title{
Review of the Current Status of the Offshoring Industry: Insights for Practice
}

\author{
Liyanachchi Mahesha Harshani De Silva ${ }^{1}$ \\ ${ }^{1}$ Assistant Lecturer, Faculty of Business, Sri Lanka Institute of Information Technology, Sri Lanka \\ Correspondence: Liyanachchi Mahesha Harshani De Silva, Assistant Lecturer, Faculty of Business, Sri Lanka \\ Institute of Information Technology, Sri Lanka. E-mail: mharshani1990@gmail.com
}

Received: October 28, 2018

Accepted: November 28, 2018

Online Published: December 18, 2018

doi:10.5539/ijbm.v14n1p76

URL: https://doi.org/10.5539/ijbm.v14n1p76

\begin{abstract}
The aim of this literature review is to analyze the current situation of the offshoring industry and relate the offshoring practices into Sri Lankan context to identify the loopholes. Thereby this review identifies the challenges and opportunities for the expansion of offshoring industry in general and specific to Sri Lanka as a destination. Based on the review of 120 offshoring articles, this study extracts the insights for practice based on popular offshoring frameworks. Mainly three key major models were identified including Chile offshore services value chain, key provider evaluation criterion and A. T Kearney Global Services Location Index. These frameworks are presented with the aim of identifying a suitable study framework for future research in relation to the Sri Lankan context. This Literature review is organized into four sections such as offshoring: definitions \& terms, current situation analysis, challenges of offshoring and research frameworks.
\end{abstract}

Keywords: offshoring, outsourcing, challenges, literature review, framework

\section{Introduction}

IT-BPO industry is the fifth largest foreign exchange earner for Sri Lanka today. It has been reported that the new opportunities to expand this industry are still in the broadening phase. The Government's vision of IT-BPO industry is to make it the top foreign revenue earner of the country by 2020 (De Silva et al., 2014). Business process offshoring industry commenced with the intensified global competition during the late 1980s when the businesses in developed countries decided to outsource their non-core business activities to offshore nations (Lokanathan, 2006). Such outsourcing of services to foreign countries is beneficial to the supplier countries as well as the service providing nations. Offshoring nations look out for developing countries like Sri Lanka to get the advantage of cheap labour while also receiving a quality service. The service providing nations receive not only economic benefits but also advanced knowledge of business processes and technology and employment opportunities. Comprehensive research studies with respect to offshoring are fast expanding around the world (De Silva et al., 2014). There are a number of studies focused on countries like India and China. The inadequacy of in-depth empirical research on Offshoring in Sri Lanka is quite evident.

The aim of this study is to extract the insights which identified for offshoring practice. From an in-depth study of literature, this study mainly classified in four main topics such as offshoring definitions and terms current situation analysis, challenges of offshoring and research frameworks, each topic is thoroughly reviewed in this paper.

\section{Offshoring: Definition \& Terms}

As a first step, it is useful to get an understanding of certain terms associated with offshoring. This is mainly because offshoring is a relatively new discipline and certain terms are being used to mean differently (Ellram, Tate, \& Petersen, 2013). Certain terms are inappropriately used by different researchers intentionally or unintentionally. In fact, what is being discussed in the literature as an "Offshoring Industry" was only at its emerging stages 20 years ago? However, due to the increasing end-user IT spending, the rapidly changing world where IT is a large part of even the smallest companies, it has become a major part of even the smallest jobs and it has transformed the workforce continuously (Blinder, 2006). Since offshoring is a variant of outsourcing it is important to establish the definition for it as follows. 
This review use the following broad definition that covers all forms of outsourcing to other countries:

"Outsourcing occurs when one company delegates responsibility for performing a function or series of tasks to another company. When the second company is based in another country, outsourcing becomes offshoring" (Lewin \& Peeters, 2006). Some research papers limit the definition of offshoring only to the IT industry. "When the supplier of software development is from another country then the firm that decides to outsource information systems" (Yeaple, 2006). This problem has been identified by certain past researchers too (Mudambi \& Venzin, 2010).

This study is not limited to a single subsector of offshoring and covers Legal Process Offshoring (LPO), Finance \& Accounting Offshoring (FAO), Call Center Offshoring(CCO) and Information Technology offshoring(ITO) (Amiti \& Wei, 2009). Certain other terms used in the offshore literature are clarified in the next paragraph.

There are some distinct types of offshoring such as Nearshore Outsourcing, Offshore and offshore outsourcing (Lewin, Massini, \& Peeters, n.d.).

Nearshore outsourcing is "the transfer of business or IT processes to companies in a nearby country, often sharing a border with your own country. Nearshoring is a popular model for companies that do not want to deal with the cultural, language, or time zone differences involved in offshoring"(Lewin \& Peeters, 2006).

Offshore is "an outsourcing term describing the provision of services from a country that is geographically remote from the client enterprises. For example, China is located far from the United States and is, therefore, an offshore destination for U.S. enterprises" (Contractor, Kumar, Kundu, \& Pedersen, 2010).

Offshore Outsourcing is the "transfer of business or IT processes to organizations in other countries" (Lewin \& Peeters, 2006). When considering IT offshoring, it offers organizations in the industry similar benefits. These include the flexibility to configure activities and services as required; access to specialized skills, for example in information technology (IT) programming, and reduction in costs. Offshoring also appears to offer additional benefits compared to domestic outsourcing as well.

Offshoree is the service providing countries. These are mainly developing countries and the topmost giants are India and China. Whereas an Offshorer is the countries who are the clients of the above countries. Mainly the US and UK. For example, in the above offshore definition, China is the Offshoree and US is the Offshorer (Metters, 2008).

It has also been noted that most past research studies are focused on the criteria for selection of the offshore service provider partners (Lacity, Khan, \& Willcocks, 2009). The value of such research is more for the offshorer rather than the offshore. It is vital for a developing country such as Sri Lanka to explore this issue from the point of view of the offshore (Gefen \& Carmel, 2008).

\subsection{Industry of Offshoring}

According to Gartner publications, the global potential for the ICT-BPO market is expected to be $\$ 1.5$ trillion, however, what can be captured with the available technology and resources is only estimated to be $\$ 500 \mathrm{bn}$ (Lokanathan, 2006). It is interesting to note that only about $25 \%$ has been captured by outsourced nations. Further, the ICT-BPO offshoring market is expected to grow up to US\$ 300 bn within the next 5 years (2011-2016) and Sri Lanka hopes to capture between 0.5\% - 1\% out of this growth (Lokanathan, 2006).

G7 Nations (USA, UK, Japan, Germany, France, Canada, and Italy) have produced much of the world's software in the first few decades of the computer era. High Tech exporting used to "belong" to these nations with the USA as the controlling power in software. According to the 3-tier taxonomy of the world's roughly 100 software exporting countries, G7 nations are still at the core of the Tier I software nations, the mature software exporting nations. They have a tradition of exporting high technology and knowledge-intensive products and services. USA with its software giants Microsoft and IBM continues to dominate the world market and other G7 nations such as Japan, Great Britain, Germany, France and Canada had successful software (and computer hardware) industries spanning for many decades (Mudambi \& Venzin, 2010).

The three "I"s (India, Ireland, Israel) have been added to the Tier I countries. All three of these countries have developed robust software export industries. The two newest entrants are China and Russia. China's software industry is maturing quickly and it is a close second only to India. Russia at this point in time may be on the edge and the future of its industry cannot be predicted as yet. Sri Lanka is classified as a Tier II nation. Which are the emerging software exporting nations? These nations are characterized by having significant software exporting industries, exporting at 25-200 Mn USD per Annum. Most nations have clusters of technology firms in major metropolitan areas or in designated technology parks. The issues with these Tier II nations are that they consist 
of small populations which are again impacting their scalability to grow to large industries, secondly unfavorable conditions such as political instability or immature stage of economic development.

Tier III nations are Infant Stage Software Exporting nations with an insignificant impact on the global software market. Companies of these countries are benefitted from FDI's but they are small one-off cases. These companies are characterized as being small and management is known to be unprofessionalized.

Table 1. A three-tier taxonomy of the world's roughly 100 software nations

\begin{tabular}{lll}
\hline Tier-1 & $\begin{array}{l}\text { Mature software exporting } \\
\text { nations }\end{array}$ & $\begin{array}{l}\text { Mostly industrialized nations such as: USA, Canada, UK, Germany, France, Belgium, } \\
\text { The Netherlands, Sweden, Finland, Japan, and Switzerland Entrants from the 1990s: } \\
\text { Ireland, Israel, and India. Entrants from the 200s; China and Russia }\end{array}$ \\
\hline Tier-2 & $\begin{array}{l}\text { Emerging software exporting } \\
\text { nations } \\
\text { Infant stage software exporting } \\
\text { nations }\end{array}$ & $\begin{array}{l}\text { Brazil, Costa Rica, Mexico, The Philippines, Malaysia, Sri Lanka, South Korea, } \\
\text { Pakistan, Ukraine, many other Eastern European countries and several more elsewhere } \\
\text { Cuba, El Salvador, Jordan, Egypt, Bangladesh, Indonesia, Vietnam, and 10-20 others }\end{array}$ \\
& $\begin{array}{l}\text { Non-competing } \\
\text { About } 100 \text { of the mostly, small, least-developed countries of the world, including most } \\
\text { African, and many Middle-Eastern nations. These nations have few to no software } \\
\text { exporting firms. }\end{array}$ \\
\hline
\end{tabular}

The majority of the software offshoring market is captured by offshoring giants that thrive in the top seats. They are commonly referred to as the "big three" which includes China, India and Russia. These giants are characterized commonly by large populations which include large well-educated labor forces in Science and Technology (Ellram et al., 2013). These countries have well-established education systems producing thousands of qualified young people (at least 100,000 per annum or more) with degrees in computer science or related fields, who has a command of a foreign language, particularly English. All three have seen substantial government investments in human capital (literacy, schools and universities). These nations have "scale" and a "deep labor pool". Scalability is one of the major challenges that countries with a relatively lower population such as Sri Lanka and Chile face. Because although BPO and KPO industry can technically take place anywhere it cannot be built or thrive without scalability according to page 21 of (Jayaweera \& Thelijjagoda, 2011). All three of these countries are actively involved in offshore software work. For example, India has become successful as a software factory, perfecting software production and delivery systems while Russia has had some success in algorithm oriented software that requires innovation and resourcefulness.

However, other than these top countries there are high number of relatively small countries such as Malaysia, Mauritius and Chile entering into the limelight to grab a share of this highly profitable market (Larsen, Manning, $\&$ Pedersen, 2013). Amongst a number of other offshore competitors, Sri Lanka is also emerging as a destination of choice for IT BPO markets.

\subsubsection{Malaysia}

This is a leading alternative to India and is ranked 3rd in the AT Kearney global services location index 2012 (Kearney, 2014). This is a remarkable feat as it is only behind India and China countries many times its size. It is specializing in R\&D and software development work. It emphasizes the quality of its business environment and infrastructure (Cooke, Shen, \& Mcbride, 2005).

The Malaysian government is leading an important initiative in developing the offshoring industry of the country. The government is known to support more offshore companies in many ways similar to Kenyan and Mauritius governments (Lewin \& Peeters, 2006). It's investment in modern IT infrastructure during the 1990's lead to the current level of development of the industry. It has vigilantly promoted its IT capabilities and attracted multinational IT companies through carefully coordinated efforts.

\subsubsection{Mauritius}

Similar to Sri Lanka, this island has emerged as a complement to India with a bilingual English and French population and a good business environment (Lokanathan, 2006). It is more than a tourist destination and it consists of a multi-cultural peaceful ethnic environment which is easy to do business in. there is high political stability and offshore financial services among many has been identified as the future path to growth. The Board of Investment of the country has worked to develop partnerships with the private sector by improving the investment climate and encouraging innovation (Khan, Niazi, \& Ahmad, 2011b). 
Mauritius has taken several initiatives for the growth of the industry such as setting up infrastructure parks, talent development initiatives and investor-friendly business policies. The country is emerging as one of the low-cost destinations in the IT and BPO sectors with low telecommunication costs due to its well-developed digital network infrastructure similar to India. The 2 fiber optic cable networks are expected to decrease the costs and increase the availability of bandwidth. The country remains and ICT conducive environment too with the highest penetration of internet users in Africa.

In conclusion, the global market for offshoring is expanding rapidly and India and China are the market leaders in the receiving end attracting the most portion of offshore services collectively, from the developed nations of the west. These two nations compete on cost due to their large size and related benefits whereas a country such as Sri Lanka will be competing on a quality basis. However, Sri Lanka is not alone in capturing a market share of this prosperous market as there is high competition, especially from other Tier II countries.

Historically, Sri Lanka is not new to offshoring industry. For example since British colonial era companies in Sri Lanka provided Accounting \& auditing services to western nations. It is interesting to note that these processes lead to western accounting professional bodies to establish accounting education institutions in Sri Lanka. The popularity of the Chartered Institute of Management Accountants (CIMA) can be seen as an offshoot of this phenomenon. These activities demonstrate that Sri Lanka has had a culture for providing offshoring services to western nations for a very long time. However, due to various known and unknown reasons, Sri Lanka seems to be facing difficulties to expand the offshoring industry at a desired rate.

Sri Lanka is emerging as the destination of choice for ITO, BPO market. Recognizing this immense opportunity, the vision of the local ITO/BPO industry is to become the top revenue earner in the next 10 years. Feasibility of this goal is apparent because despite the recession in the west ITO/BPO industry in Sri Lanka has grown by $23 \%$ during 2009. These factors would lead to believe that if the state policies and procedures are set right and the prospective local outsourced companies' work towards capturing the opportunities the desired revenue targets could be met. However, in order to reach this goal, it appears that we have a long way to go.

Published literature on current status is not clear, for example, SLASSCOM reports that there are 300 IT BPO companies in Sri Lanka; however, the SLASSCOM in another website classifies the above companies as ITES companies. The impact of this can be differing definitions leading to errors in decision making for investors as they can get confused. Future researchers will be misinformed and will base their research on unclear data.

SLASSCOM and ICTA reports indicate there are 300 IT-BPO companies. It may be noted that these statistics were based on the survey's conducted in 2005 or before. Therefore it is not sure whether the actual number of IT companies is as above. And another report on IT export value survey states that there is a population of 175 IT/ITES companies in Sri Lanka. It is surprising that these institutions speak on IT-BPO companies and is silent on other sectors. There is no significant research done to identify the differences of these technical terms and as a result, they have overlapping meanings in the literature produced so far. IT-BPO, IT/ITES, ITO, BPO are being used as interchangeable words without proper classification. There also appears to have no classification of the companies operating in Sri Lanka as to which companies belong to which of the above sectors.

A number of industry subsectors of offshoring are identified in the literature. They include Finance \& Accounting offshoring, Information Technology Offshoring, Legal Process Offshoring, Call Center Offshoring, and Human Resource Offshoring. Only very little information is available on the current status of subsectors of offshoring. The following captions provide some insights into the four subsectors focused on this study.

A common finding in the literature is that well- developed infrastructure exists in Sri Lanka with eight telecom operators providing service to the entire nation. It is connected to the world with three international submarine cables providing ample redundancy. Colombo has a well-established road network as well as modern office facilities and support infrastructure.

FAO- Sri Lanka is recognized as a niche center of excellence for finance \& accounting outsourcing owing to Sri Lanka has the world's 2nd largest pool of UK qualified accountants. Global services magazine ranked Sri Lanka among the top 20 centers of excellence for FAO in the world. The government, however, needs to brand the country as an FAO/BPO destination. There are many successful cases due to proper marketing and branding such as the Philippines and India. Sri Lanka still has an image as a high-risk country, due to the war; with not enough being done to re-position the country now that the conflict has ended. However, there are many companies that have set up FAO operations in Sri Lanka including WNS, Amba Research \& HSBC.

ITO- ITO is defined as the contractual vehicle through which enterprises use external sources to provide lifecycle service and support operations for their IT infrastructure. The high market growth rate in this area 
offers a unique advantage for SME's to enjoy premium access to Sri Lanka's tier 1 talent pool. "Sri Lanka has a number of joint ventures with smaller economies in Ireland within Europe and Scandinavia, with the typical company size of 50-150 employees. 75\% of the ITO- BPO companies in Sri Lanka are SME's and 65\% of them are Foreign Direct Investment's (FDI). Several European SME's have started R\&D centers in the country". The government's focus on the development of IT and the highly skilled workforce makes ITO one of Sri Lanka's main strengths.

LPO- This sector is the least researched in the offshoring industry of Sri Lanka. However, it has been an emerging trend in India and much research has been done. In India, LPO is growing fast and is already the fastest growing subsector in the KPO domain because even during the recession the industry grew by $40 \%$ thus offering a viable offshoring sector to Sri Lanka as well.

Call Centers (CCO)- Among the top choices for offshoring call centers, India is the first choice but organizations have recently chosen the Philippines instead (Schoenherr, Rao Tummala, \& Harrison, 2008). Among the destinations the Philippines is rated the highest in financial structure, India leads in people skills and availability while Singapore is rated the highest in the business environment category. Research done for this area is less in the Sri Lankan context but the number of research done is high for countries like the Philippines which are emerging as strong competitors to India. This is mainly because of their American-English accent, its lower cost of labor which nearly matches India (India $12 \%$ of US levels whereas Philippines $13 \%$ ), and most importantly its large pool of suitable labor (compared to the population size) for multinational countries. India has thus far, been dominant in attracting these jobs, but it is beginning to show the strains of sustained demand. In India's most popular offshoring centers, supply constraints are now evident in rising wages and high turnover among engineers. Smaller economies now sense a real opportunity to take some of the strain of strong demand- and a larger slice of the action.

In conclusion to the Sri Lankan context, the literature available about the local industry is not clear and it is not updated. This is a major hindrance to study for future researchers as well as it is also a reason for confusion among potential investors and the like. The research on the local industry is limited and the research documents that are available are also paid documents which as students we were unable to afford.

\subsection{Challenges of Offshoring}

The challenges of Offshoring from Sri Lanka's point of view as an offshore country have been studied scarcely by previous researchers. Even in those reports that have researched the matter the offshoring industry point of view has not being taken into account but the IT-BPO industry challenges have been discussed. Even in the above current status analysis, it was apparent that the information available in reports was not classified and the information presented has not being updated.

The research "The challenges of Sri Lanka becoming an IT-BPO Destination" identifies the challenges of Sri Lanka becoming a top IT-BPO destination and provides suggestions to overcome the identified challenges (Jayaweera \& Thelijjagoda, 2011). It lists three main challenges which are: Cumbersome documentation \& procedural activities, inadequate labor force, insufficient infrastructures such as data communication, electricity and transport. As a solution to the cumbersome documentation procedures, the researcher suggests a centralized body that can help to facilitate the many lengthy processes of documentation, BOI approval etc (De Silva et al., 2014). As a response to the inadequate labor force, it must be noted that even though the labor force is high in Sri Lanka they lack the skills required for BPO industry functions. The government must improvise on ways to educate the employee base on this industry and on the skills required. The government can start from school student's level and move upwards in the career progression to create the required talent pool. Brain drain is another matter that has taken the toll on the country's economy and the government must find methods to curb this activity. There are methods to reverse the brain drain which have been implemented in Nigeria, Chile as well as India and China (Metters, 2008). The citizens of India and China who have gone to the united states or western Europe for their graduation remained there to work, began to return home in larger number, creating a reverse Diaspora effect that provided highly educated and experienced workers about western businesses and technically sound managers to these countries (Khan, Niazi, \& Ahmad, 2011a). The case of Nigeria suggests that Nigerians living overseas can create a channel for developing the reputation of Nigeria's offshore service industry (Lewin, Massini, \& Peeters, 2009). The Nigerian government can encourage this by promoting dual citizenship, compiling a database of expatriate Nigerian professionals and mobilizing its embassies to support such an effort (Radwan \& Strychacz, 2010).

The researcher suggests the following improvements; to build more knowledge parks at attractive prices with all the required facilities such as high capacity reliable data/voice links, economical tariffs designed for this sector 
and backup power facilities. An additional suggestion is that the government should provide locations for foreign investors for a free of charge testing period which is predefined. There should also be intelligent buildings which let the foreign companies to speedily plug and play therefore save time in starting up operations in the country. Also for utility costs, the government will have to perform active negotiations with the relevant service providers to attract a lower cost for the foreign companies (Marin, 2006). The government can utilize the idle capacity of government transport to ensure that BPO employees are ensured safe and reliable transportation at an affordable cost during the off-peak hours they work in.

Since Chile as a country is similar to Sri Lanka studying its challenges is also worthwhile. The challenges of the Chile case study is subdivided into segments such as ITO, BPO, KPO and vertical industry issues (Head, Mayer, \& Ries, 2009). There are common challenges in the above-mentioned segments. In the ITO sector in order to improve competitiveness and become a center for innovative services in the IT industry these challenges must be overcome: there are only a handful companies having CMMI level 5 certification which is necessary for attracting important contracts. Chile has a long way to train the engineers and technicians for this field. Greater effort needs to be extended in connecting with industry in curriculum development. The students need to broaden their outlook on the world and improve skills in marketing and entrepreneurship. While the offshoring industry provides positive spillover benefits to Chile as well as many other countries such as India and Nigeria while foreign tech entrepreneurs are eligible for the high technology incentive program, funding opportunities for Chilean entrepreneurs remain scarce. The Chilean labor laws are stringent and working long hours will stifle creativity in the research and development sector. The key recommendations for this sector are to establish a presence close to the key markets to develop strong relationships with clients. Closer relationships between universities and education institutes to improve the flow of qualified human capital; since Chile has a limited number of IT professionals in the country it is important to improve the skill levels of these professionals. This is vital because Chile cannot compete on quantity efforts must be focused on improving the quality of the services provided. The industry must implement promotion policies to support companies developing high niche software rather than standard IT capabilities. Finally, it should incentivize the inclusion of new technologies such as cloud computing. This would depend mostly on a reliable telecommunication infrastructure.

The BPO industry of Chile has been key in ranking the country as a top BPO destination. But the services currently provided by the Chilean companies in this sector are highly repetitive and make up the lower end of the offshore services value chain mentioned in the next section. The challenge the country now faces is to upgrade into higher value activities that will insert Chile into the knowledge economy and transform the country into a select group of offshore KPO and innovation destinations. This is the same challenge that Sri Lanka now faces.

Chile has a high labor cost compared to its Latin American peers with high attrition rates. Chilean labor laws require greater flexibility for employees to work round the clock. This is consistent with South Asia which has the highest firing costs in comparison with other countries in the region. Lengthy court battles in Sri Lanka can incur substantive legal expenses and inefficient use of resources. The main recommendation for the BPO sector is to upgrade to higher value-added activities such as consulting, customer analysis where technical skills are more relevant than English language skills. The government should offer new incentives for existing companies who are ready to upgrade to higher value-adding activities.

Most leading firms in India, Ireland are all beginning to compete in this sector as there is potential for high-value generation in this sector. The greatest challenge is that the use of the term KPO is very broad and is not consistently used. This is apparent in most literature. KPO operations require higher-level initial capital investments, especially in the human capital. The recommendations are to approach the companies that are already in the country in the BPO segment that offer KPO services in other parts of the world. Offer training initiatives for the development of these service offerings in Chile. Offer an English program directed to professionals in this field to improve English capability.

In conclusion, the research conducted on the challenges of the Offshoring sector specifically in Sri Lanka is limited. The research that existed is not classified and updated. The research identified in this part of the review is focusing on the IT-BPO sector of Sri Lanka and not the Offshoring industry. Since Chile is similar to Sri Lanka in context and has much of the same issues in developing their offshore industry it is noteworthy to assess the issues faces by the country and the ways they overcome the issues.

\subsection{Research Framework}

Initially many frameworks for offshore development were identified but it has been narrowed down to two due to the suitability for this review work. I.e. the AT Kearney global services location index and the Chile offshore service value chain. Additionally, a key provider evaluation criterion has been identified (Kearney, 2014). This 
relates directly to the offshore but prospective offshore countries such as Sri Lanka can capitalize on these factors to attract more offshoring services to them.

The Chile offshoring services value chain: Even though the Chilean offshoring industry has rapidly evolved the three sectors remain to be seen that is ITO (Information Technology outsourcing), KPO (Knowledge process outsourcing) and BPO (Business Process Outsourcing). The subcategories also have been included under the above sections. It is clear which activities are high and low value adding and which to undertake or not.

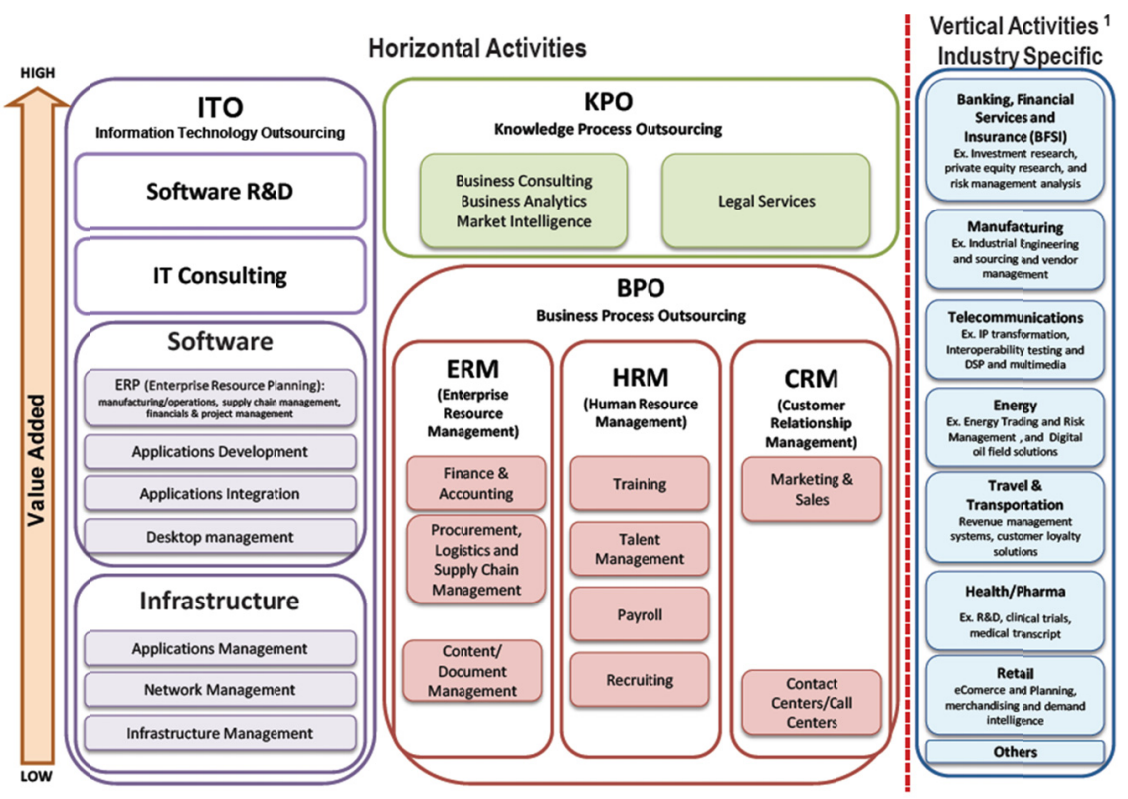

Figure 1. Chile offshoring services value chain

Source: Duke CGG.

Key provider evaluation criteria: this is mainly from the offshorer point of view. There are various measurable/hard criteria such as cost, experience and also there are also soft elements such as organizational culture and language which are crucial but easily overlooked (Kinkel \& Maloca, 2009). Generally, the importance of these criteria is different from company to company. For some investments, they might consider all of the below criteria but some might consider only a few (Ho, Xu, \& Dey, 2010). It will be useful to assign weights in the criteria to measure the scores in a matrix (Aubert, Rivard, \& Patry, 1996).

The AT Kearney offshore location attractive index is used to evaluate the prospective destinations around the globe. It consists of three major categories which include financial attractiveness, people skills and availability and business environment (Kearney, 2014). Since cost structure was determined to be the primary motive for offshoring decisions financial attractiveness was assigned the weight of $40 \%$ while people skills and availability scored $30 \%$ each (Kearney, 2014). In the AT Kearney global services location index the financial attractiveness of the country is higher than that of the business environment and the people skills. 


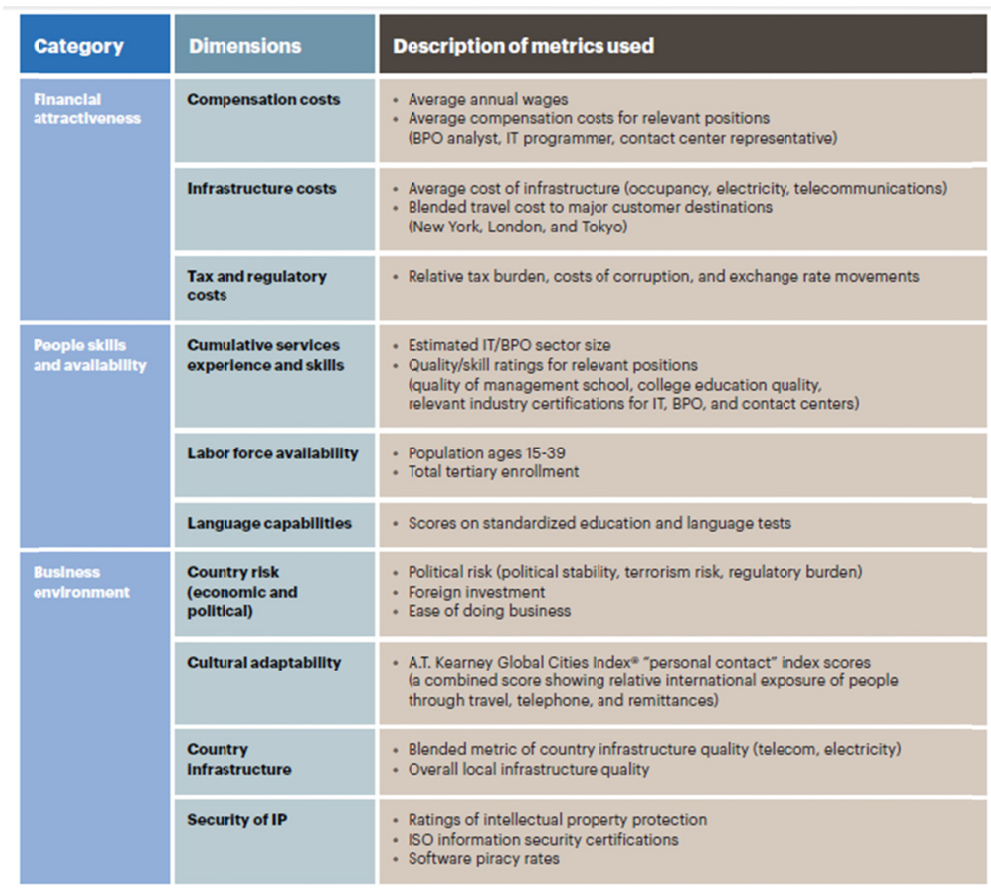

Source: A. T Kearney Analysis

In conclusion, this model is good for analyzing the current status of the country. In order to understand the current situation, we use this model as the theoretical framework.

\section{Conclusion}

The aim of this literature review is to analyze the current situation of the offshoring industry of Sri Lanka. The challenges and opportunities for the global industry, as well as the Sri Lankan industry, are also identified. This Literature review is organized into four sections. They are offshoring: definitions \& terms, current situation analysis, challenges of offshoring and theoretical framework.

Currently, the global market for offshoring is expanding rapidly and India and China are the market leaders in the receiving end attracting the most portion of offshore services collectively, from the developed nations of the west (Lee, 2001). Due to the attractiveness of the industry, there are many small-scale players who have similar characteristics. There is heavy competition between these players as they try to capture a market share of this prosperous market (Lee \& Kim, 1999).

In the Sri Lankan context, the literature available about the local industry is not clear and it is not updated which is a major hindrance to study for future researchers as well as it is also a reason for confusion among potential investors and the like. The research on the local industry is limited and the research documents that are available are also paid documents which as students we were unable to afford. The research that existed is not classified and updated. The literature review is focusing on the IT-BPO sector of Sri Lanka and not the Offshoring industry.

\section{References}

Amiti, M., \& Wei, S. J. (2009). Service Offshoring and Productivity: Evidence from the US. World Economy, 32(2), 203-220. https://doi.org/10.1111/j.1467-9701.2008.01149.x

Aubert, B. A., Rivard, S., \& Patry, M. (1996). A transaction cost approach to outsourcing behavior: Some empirical evidence. Information \& Management, 30(2), 51-64. https://doi.org/10.1016/0378-7206(95)00045-3

Blinder, B. A. S. (2006). Offshoring : The Next Industrial Revolution? Foreign Affairs, 113-128.

Contractor, F. J., Kumar, V., Kundu, S. K., \& Pedersen, T. (2010). Reconceptualizing the Firm in a World of Outsourcing and Offshoring: The Organizational and Geographical Relocation of High-Value Company Functions Farok J. Contractor, Vikas Kumar, Sumit K. Kundu and, (December). https://doi.org/10.1111/j.1467-6486.2010.00945.x 
Cooke, F. L., Shen, J., \& Mcbride, A. (2005). Outsourcing HR as a competitive strategy? A literature review and an assessment of implications. Human Resource Management, 44(4), 413-432. https://doi.org/10.1002/hrm.20082

De Silva, L. M. ., Hewavitharana, K. I. D. M., Fernando, K. A. D. S., Perera, J. K. S., Kahandawarachchi, C., \& Suraweera, T. (2014). Strategies for the Development of Offshoring Industry in Sri Lanka. Colombo: NITC. Retrieved from http://dspace.sliit.lk/handle/123456789/242

Ellram, L. M., Tate, W. L., \& Petersen, K. J. (2013). Offshoring and Reshoring: An Update on the Manufacturing Location Decision. Journal of Supply Chain Management, 49(2), 14-22. https://doi.org/10.1111/jscm.12019

Gefen, D., \& Carmel, E. (2008). Is the World Really Flat? A Look at Offshoring at an Online Programming Marketplace. MIS Quarterly, 32(2), 367. https://doi.org/10.2307/25148844

Head, K., Mayer, T., \& Ries, J. (2009). How remote is the offshoring threat? European Economic Review, 53(4), 429-444. https://doi.org/10.1016/J.EUROECOREV.2008.08.001

Ho, W., Xu, X., \& Dey, P. K. (2010). Multi-criteria decision making approaches for supplier evaluation and selection: A literature review. European Journal of Operational Research, 202(1), 16-24. https://doi.org/10.1016/J.EJOR.2009.05.009

Jayaweera, M., \& Thelijjagoda, S. (2011). The Challenges of Sri Lanka Becoming an IT-BPO Destination. Retrieved from http://repository.kln.ac.lk/handle/123456789/2853

Kearney, A. T. (2014). Global Services Location Index - A.T. Kearney. Global Services Location Index 2014, (Sep. 2014), 1. Retrieved from https://www.atkearney.com/research-studies/global-services-location-index

Khan, S. U., Niazi, M., \& Ahmad, R. (2011a). Barriers in the selection of offshore software development outsourcing vendors: An exploratory study using a systematic literature review. Information and Software Technology, 53(7), 693-706. https://doi.org/10.1016/J.INFSOF.2010.08.003

Khan, S. U., Niazi, M., \& Ahmad, R. (2011b). Factors influencing clients in the selection of offshore software outsourcing vendors: An exploratory study using a systematic literature review. Journal of Systems and Software, 84(4), 686-699. https://doi.org/10.1016/J.JSS.2010.12.010

Kinkel, S., \& Maloca, S. (2009). Drivers and antecedents of manufacturing offshoring and backshoring-A German perspective. Journal of Purchasing and Supply Management, 15(3), 154-165. https://doi.org/10.1016/J.PURSUP.2009.05.007

Lacity, M. C., Khan, S. A., \& Willcocks, L. P. (2009). A review of the IT outsourcing literature: Insights for practice. Journal of Strategic Information Systems, 18(3), 130-146. https://doi.org/10.1016/j.jsis.2009.06.002

Larsen, M. M., Manning, S., \& Pedersen, T. (2013). Uncovering the hidden costs of offshoring: The interplay of complexity, organizational design, and experience. Strategic Management Journal, 34(5), 533-552. https://doi.org/10.1002/smj.2023

Lee, J. N. (2001). The impact of knowledge sharing, organizational capability and partnership quality on IS outsourcing success. Information \& Management, 38(5), 323-335. https://doi.org/10.1016/S0378-7206(00)00074-4

Lee, J. N., \& Kim, Y.-G. (1999). Effect of Partnership Quality on IS Outsourcing Success: Conceptual Framework and Empirical Validation. Journal of Management Information Systems, 15(4), $29-61$. https://doi.org/10.1080/07421222.1999.11518221

Lewin, A. Y., \& Peeters, C. (2006). Offshoring Work: Business Hype or the Onset of Fundamental Transformation? Long Range Planning, 39(3), 221-239. https://doi.org/10.1016/J.LRP.2006.07.009

Lewin, A. Y., Massini, S., \& Peeters, C. (2009). Why are companies offshoring innovation? The emerging global race for talent. Journal of International Business Studies, 40(6), 901-925. https://doi.org/10.1057/jibs.2008.92

Lewin, A. Y., Massini, S., \& Peeters, C. (n.d.). Why Are Companies Offshoring Innovation? The Emerging Global Race for Talent Why Are Companies Offshoring Innovation? The Emerging Global Race for Talent, (2007), 1-54.

Lokanathan, S. (2006). Business Process Outsourcing. Colombo: ICTA.

Marin, D. (2006). A New International Division of Labor in Europe: Outsourcing and Offshoring to Eastern 
Europe. Journal of the European Economic Association, 4(2-3), 612-622. https://doi.org/10.1162/jeea.2006.4.2-3.612

Metters, R. (2008). History of offshoring knowledge services. Journal of Operations Management, 26(2), 141-147. https://doi.org/10.1016/J.JOM.2007.02.012

Mudambi, R., \& Venzin, M. (2010). The Strategic Nexus of Offshoring and Ram Mudambi and Markus Venzin. Journal of Management Studies, (December). https://doi.org/10.1111/j.1467-6486.2010.00947.x

Schoenherr, T., Rao Tummala, V. M., \& Harrison, T. P. (2008). Assessing supply chain risks with the analytic hierarchy process: Providing decision support for the offshoring decision by a US manufacturing company. Journal of Purchasing and Supply Management, 14(2), 100-111. https://doi.org/10.1016/J.PURSUP.2008.01.008

Yeaple, S. R. (2006). Offshoring, Foreign Direct Investment, and The Structure Of U.S. Trade, 4(May), 602-611.

\section{Copyrights}

Copyright for this article is retained by the author(s), with first publication rights granted to the journal.

This is an open-access article distributed under the terms and conditions of the Creative Commons Attribution license (http://creativecommons.org/licenses/by/4.0/). 